\title{
Contamination intensity and origin of trace metals in the bottom sediments from the Sebou basin (NW Morocco)
}

\author{
Sara EL MRISSANI 1,2, , Souad HAIDA ${ }^{2}$, Jean-Luc PROBST ${ }^{1}$, Anne PROBST 1,* \\ Received: date; Accepted: date; Published: date \\ Academic Editor: name \\ 1 Laboratoire écologie fonctionnelle et environnement, Toulouse University, CNRS, Toulouse, France; \\ anne.probst@ensat.fr \\ 2 Géosciences des Ressources Naturelles, Ibn Tofail University, Kenitra, Morocco; haida.souad@uit.ac.ma \\ * Correspondence: anne.probst@ensat.fr; Tel.: +33-(0)5-34-39-42
}

\begin{abstract}
Due to increasing anthropogenic activities, trace elements (TE) remain a major concern particularly in semi-arid countries of limited water resources. In this context, the present study aimed at understanding the geochemistry of trace elements in bottom sediments from the Sebou basin, representing $1 / 3$ of the surface water resources of Morocco. Total concentrations of trace elements ( $\mathrm{As}, \mathrm{Cd}, \mathrm{Co}, \mathrm{Cr}, \mathrm{Cu}, \mathrm{Ni}, \mathrm{Pb}, \mathrm{Zn}$ ) and some physico-chemical parameters were measured in the fraction $<63 \mu \mathrm{m}$. The order of abundance of the elements was $\mathrm{Zn}>\mathrm{Cr}>\mathrm{Cu}>\mathrm{Ni}>\mathrm{Pb}>\mathrm{Co}>\mathrm{As}>\mathrm{Cd}$. The enrichment factor calculation showed that $70 \%$ of the samples were naturally concentrated in trace elements, specially $\mathrm{As}$ and $\mathrm{Ni}$, as well as $\mathrm{Cd}$ and $\mathrm{Pb}$, except in some stations. On the opposite, the most enriched elements were $\mathrm{Cr}, \mathrm{Zn}$ and $\mathrm{Cu}$. Chromium presented an enrichment higher than 5 and toxicity risks at some stations, such as downstream the Fez city known for its important tanneries activities. A multi-variate analysis of the datas evidenced the strong link between the identified natural elements (As, $\mathrm{Co}, \mathrm{Ni}$ ) with clays, $\mathrm{Fe}$, Al oxides, whereas elements $(\mathrm{Cd}, \mathrm{Cu}, \mathrm{Cr}, \mathrm{Pb}, \mathrm{Zn})$ mainly originating anthropogenic activities (industrial and domestic wastes, agricultural inputs), were linked to phosphorus, to a lesser extent to particulate organic carbon.
\end{abstract}

Keywords: Sediments, trace elements, Sebou basin, contamination, controlling factors.

\section{Introduction}

The development of anthropogenic activities (agricultural, mining, industrial, artisanal, domestic...) has a very visible impact on the quality of aquatic environments. This impact is more important when effluents are discharged without any pre-treatment [1]. The input of contaminants, especially trace elements (TE), affects benthic species and human health because of their persistence, toxicity, and capacity to be bioaccumulated through the food chain $[2,3]$. One of the best way to assess the contamination of rivers by trace elements from natural and anthropogenic sources, is to investigate bottom sediments $[4,5,6]$. Indeed, the sediments have a high retention capacity of trace elements and act as a sink for pollutants $[7,8]$. The components of sediments (iron and manganese oxides, clays, organic matter, carbonates and the residual faction) mainly control these elements [9]. However, the behaviour of trace elements in sediment depends on several biogeochemical processes [10]. Under certain physicochemical conditions, such as $\mathrm{pH}$, dissolved oxygen, or redox potential, they can be released in the dissolved phase and become bioavailable [11,12]. Semi-arid basins, characterized by long dry low-water periods, are mostly sensitive to trace elements contamination $[13,14]$ as it is the case for the Sebou basin.

The Sebou basin includes one of the most important hydrographic network in Morocco, representing $1 / 3$ of the surface water resources of the country [15]. However, the rapid development of artisanal and industrial activities, the population growth, modernization, and intensification of agriculture, have decreased the quality of the Sebou River [16]. Today, it is considered as one of the 
most polluted rivers in Morocco [17]. Several studies have been carried out to identify trace element contamination in the Sebou basin, but most of them have been focused on the biological and physicochemical study of water and sediments in the Fez sub-basin [1, 12, 18-21].

The present study aims to investigate the origin and controlling factors of trace metals in the river bottom sediments at the basin scale of the fluvial part of the Sebou Basin during various seasonal conditions.

\section{Materials and Methods}

\subsection{Study area}

The Sebou basin is located in the north-west of Morocco (Fig.1). The fluvial part of our concern, extends over an area of $26200 \mathrm{~km}^{2}$. It is a carbonate basin characterized by calcareous rocks, dolomites, marls, marly calcareous, and evaporites. Three geomorphological units can be distinguished [22]: the Upper (Middle Atlas), Middle (Rif and Pre-rif mountain), and Lower Sebou basin (Gharb plain). The climate is of Mediterranean type with an oceanic influence. The average rainfall varies between 600 to $1000 \mathrm{~mm}$ and the temperature between 10 to $20^{\circ} \mathrm{C}$.

The annual surface water inflow of the Sebou River $\left(5600 \mathrm{Mm}^{3}\right.$.year-1) is very irregular in space and time. The hydrological regime depends strongly on the main tributaries right bank (the Lben, the Inaouen and the Ouergha, Fig.1). Ten main dams occur in the Sebou basin, the most important one being Al Wahda with a storage capacity of $3714 \mathrm{Mm}^{3}[16]$.

The suitable agricultural area is about 1,9 million hectares (around $20 \%$ of the national potential). The principal crops concern cereals, vegetables, cane sugar, sugar beet, oleaginous plants, citrus, and vineyards [16]. The most important anthropogenic units are quarries, paper industry, sugar refineries, oil extraction, and tanneries.

Around $86 \%$ of domestic wastewater are discharged into the watercourse [17]. The city of Fez alone generates $40 \%$ of these discharges [1]. The main identified polluting activities are tanneries, textiles and paper industries, which produce copper, lead, nickel, and sulfides. Liquid wastes from food processing industries (oil, sugar, dairy products, etc.) generate biological inhibition in the aquatic ecosystem due to the high level of organic matter concentration [1]. During the periods of those liquid discharges, dam releases are carried out to dilute the pollutant load in order to improve the water quality of the Sebou River.

\subsection{Sampling and pre-treatment of samples}

Four spatial sampling campaigns have been carried out in 2018 and 2019 during contrasted hydrological periods and seasons (Mars 2018 : high flow; July 2018, April 2019, July 2019 : low flow. The discharge during these four campaigns at the outlet station (S6) was 486.53,50.1, 5.2, and 24.1 m3.s-1 ${ }^{-1}$, respectively).

Surface sediments $(0-5 \mathrm{~cm})$ were taken from 10 stations on the Sebou River (code S) and its tributaries (Fez, Innaouen, Lben, and Ouergha) (code A, Fig. 1). These stations were selected in order to survey the main water course of the Sebou River (from upstream to downstream), and the changes occurring after the confluence with the tributaries. The surface sediment samples were collected from the border of the river, under water, and they were stored in polyethylene bottles. Once in the laboratory, the samples were air-dried, quartered, gently disaggregated in an agate mortar, and sieved into three fractions $(2000-200 \mu \mathrm{m}, 200-63 \mu \mathrm{m}$, and $\leq 63 \mu \mathrm{m})$. 


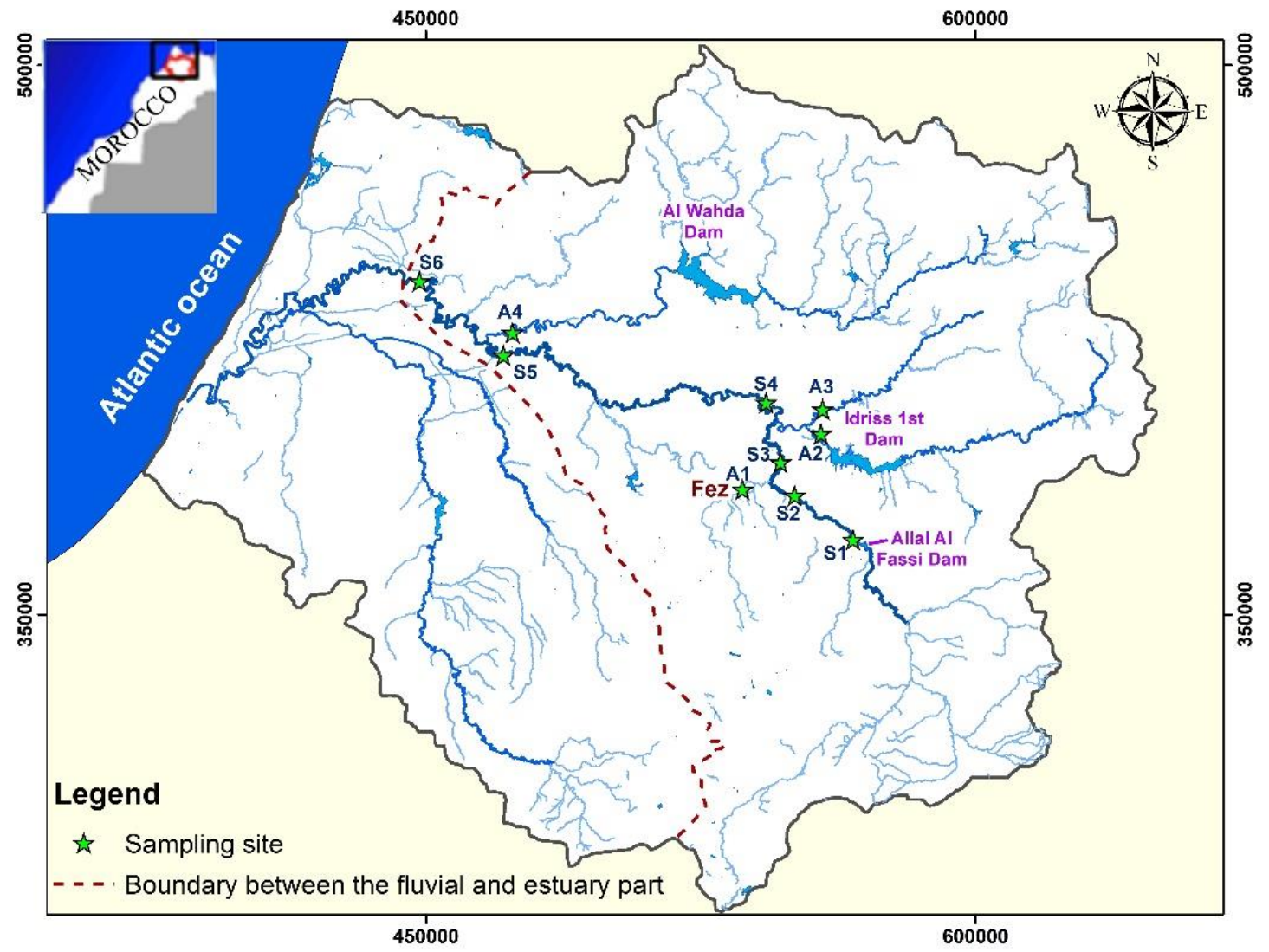

Figure 1. The Sebou basin (North-West of Morocco) and location of the sampling stations form upstream to downstream: along the Sebou main course (from S 1 to S6) and the tributaries (from A1 to A4).The red dash line delimited the considered sub-basin at Machraa Bel Ksiri city (S6)

\subsection{Physico-Chemical treatments and analysis}

At the Laboratoire écologie fonctionnelle et environnement (Toulouse, France), a microgranulometric analysis was performed on the total fraction $(\leq 2 \mathrm{~mm})$ and the fine fraction $(\leq 63 \mu \mathrm{m})$ with a Horiba LA 950 laser microgranulometry. Total concentrations of major and trace elements were measured in the fine fraction $(<63 \mu \mathrm{m})$, after complete dissolution using the alkaline fusion method with lithium metaborate [23], with an inductively Coupled Plasma-Mass Spectrometer (ICPMS) at the Service d'Analyse des Roches et des Minéraux (SARM) of the Centre for Petrographic and Geochemical Research (CRPG, Nancy, France). Blanks and certified standard sediments are used following standardized and validated methods [24]. Particulate organic carbon (POC) was analyzed with a Flash 2000 ThermoFisher, after a inorganic carbon removal with hydrochloric acid (HCL, 2N) on a hot plate $\left(60^{\circ} \mathrm{C}\right)$.

\subsection{Enrichment Level Assessment}

The assessment of trace element concentration in sediments is necessary but it is not a sufficiant way to identify the contamination level and origin [25-26] . Many authors have used the enrichment factor [26, eq.1] as an indicator of the anthropogenic contribution of trace elements concentrations [5,27-28].

$$
\mathrm{EF}=(\mathrm{X} / \mathrm{R})_{\text {Sample }} /(\mathrm{X} / \mathrm{R}) \text { Background }
$$


Where $(\mathrm{X} / \mathrm{R})$ sample and $(\mathrm{X} / \mathrm{R})$ Background are the ratios between the concentrations of the trace element and the normalizing element in the sample and in the reference material, respectively.

In this study, Aluminum (Al) was selected as the normalizing element because it is a rather conservative element, a major constituent of clay minerals, and it exhibit a very significant correlation with most of the trace elements [29]. UCC was world wildely used as a reference material, but it may led to misenterpration because of regional bedrock particularities [5]. Considering the absence of the local reference material for the Sebou basin, we used the bedrock composition of the close Tafna basin (northwest Algeria, [14]).

Five levels of trace elements enrichment in sediments can be defined [30]: 0 to 2: deficiency to low; 2 to 5: moderate enrichment; 5 to 20 : significant enrichment; 20 to 40 : very rich enrichment; $\geq 40$ : extremely high enrichment.

\subsection{Data treatement}

Data treatment was carried out using Excel (2010) and SPSS statistic 21 software. The maps were generated using ArcMap 10.2.2. The data used for the principal component analysis were centered and reduced by SPSS software.

\section{Results and discussion}

\subsection{Sediment texture and elemental composition}

Particle size analysis of the total fraction $(\leq 2 \mathrm{~mm})$ showed that $76 \%$ of the measured samples contain more than $57 \%$ of the fine fraction $\leq 63 \mu \mathrm{m}$ (fine silts, coarse silts, and clays). This fraction ( $\leq 63$ $\mu \mathrm{m}$ ) is dominated by fine silts with mean values of $70 \%$ and $61 \%$ during spring and summer periods, respectively.The particulate organic carbon (POC) in the sediments was low $(0,9 \%)$ with no variation between seasons. No relationship was found between POC and the sediment texture, or with major and trace elements, except for $\mathrm{Pb}$ (avoiding two outlaiers : $\mathrm{r}=0,79 \mathrm{n}=32$, $\mathrm{p}<0,05$ ).

The analytical results showed that $\mathrm{Si}, \mathrm{Al}, \mathrm{Fe}, \mathrm{Ca}, \mathrm{Mg}$, $\mathrm{K}$, and $\mathrm{Na}$ constitute more than $75 \%$ of the geochemical composition of the sediments. This si consitent with the lithology of the Sebou basin, which is essentially composed of carbonates and marl rocks characterized by a dominance of limestone and aluminosilicates.

The order of abundance of trace element in sediments was $\mathrm{Zn}>\mathrm{Cr}>\mathrm{Cu}>\mathrm{Ni}>\mathrm{Pb}>\mathrm{Co}>\mathrm{As}>\mathrm{Cd}$ (Fig.2). The mean trace element content of the Sebou sediments were compared to other rivers flowing through carbonate basins. Concentrations in the Sebou basin were higher than those observed on the North African Tafna basin (North-East Algeria, [14]) except for Pb, but they were lower for ex. than those observed in the Upper Pearl river basin (China, [31]). The standard deviation indicates a higher dispersion of concentrations for $\mathrm{Zn}, \mathrm{Cr}$, and $\mathrm{Pb}$. The highest average concentrations for $\mathrm{Cd}, \mathrm{Cu}, \mathrm{Cr}$, $\mathrm{Zn}$, and $\mathrm{Pb}$ were found at $\mathrm{S} 3$, for $\mathrm{As}$ at $\mathrm{S} 1$, for $\mathrm{Ni}$ at $\mathrm{A} 1$, and $\mathrm{Co}$ at $\mathrm{A} 3$ and $\mathrm{A} 4$ stations (Fig.2). 

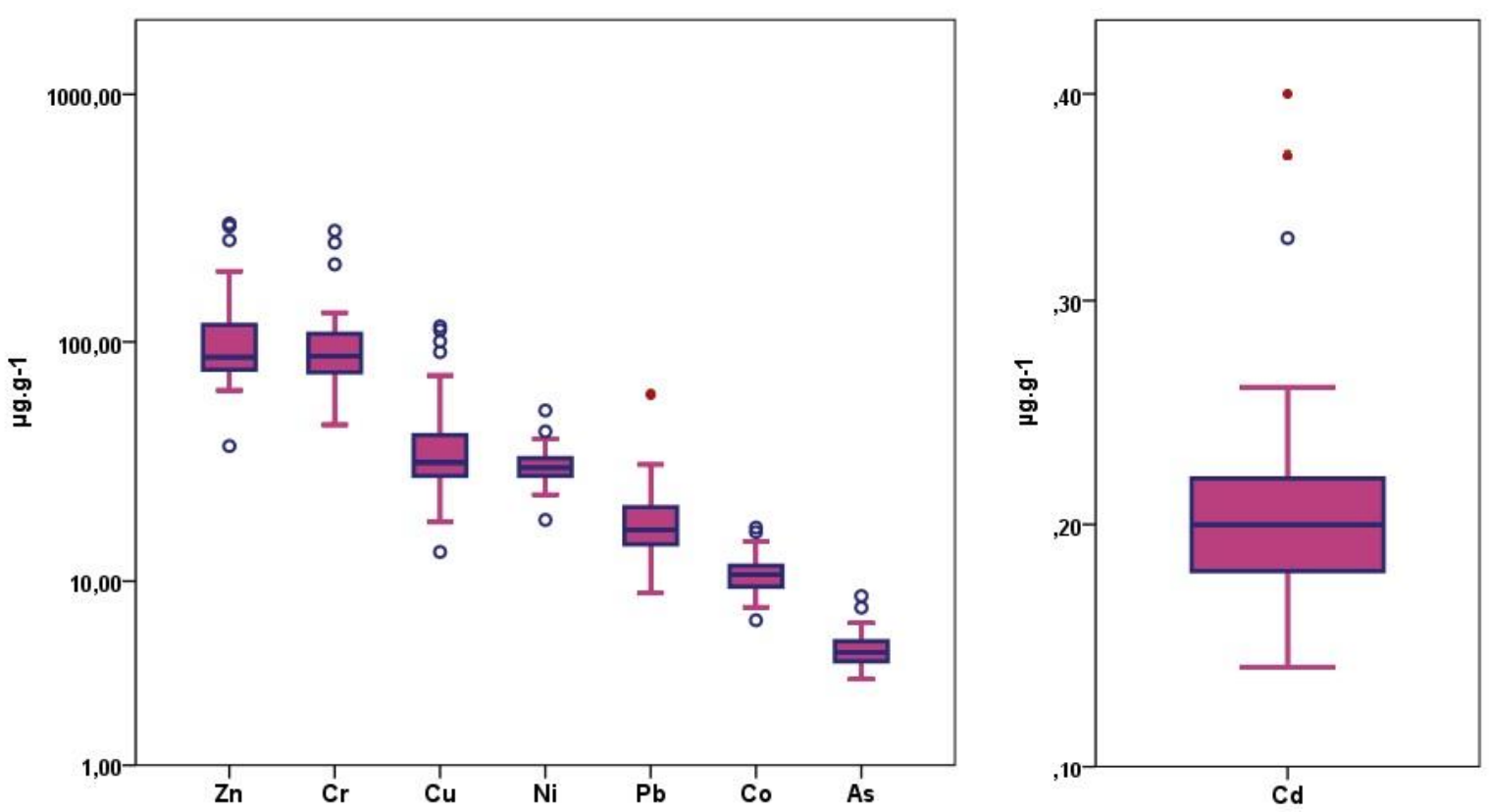

Figure 2. Box plot of the TE concentrations in bottom sediments from the Sebou basin. Notice that concentrations are expressed in log, except for $\mathrm{Cd}$.

\subsection{Enrichment Factor (EF)}

The EF showed that $70 \%$ of the samples were naturally enriched in trace elements $(\mathrm{EF} \leq 1,5$, deficiency to low), especially $\mathrm{As}$ and $\mathrm{Ni}$, as well as $\mathrm{Cd}$ and $\mathrm{Pb}$, if we except some stations (Fig. 3). Even for some elements, the EF is lower than one, indicating a natural enrichment of the sediments compared to the Tafna bedrock.

The highest $\mathrm{EF}$ values for $\mathrm{Zn}, \mathrm{Cr}, \mathrm{Cu}, \mathrm{Ni}, \mathrm{Pb}$, and $\mathrm{Zn}$ are observed at site $\mathrm{S} 3$ (Fig.3). High enrichment were also observed at station $\mathrm{A} 1$ for $\mathrm{Zn}, \mathrm{Cu}, \mathrm{Pb}$ and at $\mathrm{S} 4$ for $\mathrm{Cu}$ and $\mathrm{Cr}$. The enrichment of trace elements in the $\mathrm{S} 3$ station might be due to the liquid discharge of the Fez city, which are known to be very concentrated with these contaminants [1]. These authors mentionned very high concentrations of some major (SO4) and trace elements $(\mathrm{Cr}, \mathrm{Cu}, \mathrm{Ni}, \mathrm{Pb})$ due to the use of some chemicals in the manufacturing process in the tannery discharges and/or in the metal finishing facility discharges, respectively [1]. The very low $\mathrm{pH}$ (between 3.2 and 4.2, [1]) for effluents registered from tanneries, metal finishing facilities, and oil mills, favored metal dispersion downstream. Moderate enrichment of $\mathrm{Cr}$ and Co were observed at almost all sampled stations, which can be related either to the presence of impurities (naturally present in the raw materials) in phosphate fertilizers, or to an overestimation regarding the chosen reference material.However, to evaluate the risk of these metals enrichment, it is necessary to evaluate their availability using extractions procedures [9] (El Mrissani PhD, in progress). 




Figure 3. Enrichment factor of trace element in sediments from the Sebou basin normalized to theTafna bedrock [29]. The upper outliers (above 1.5) are for stations S3, S4 and A1. Mostlly the orange circles indicate the Fez station (S3).. The dash lines green and red indicate EF value of 1,5 and 5, respectively.

\subsection{Origin and controlling factors of trace elements}

A principal component analysis (PCA) was performed on the average concentrations of trace metals and major elements, with some key parameters (Clay, fine Silt (FS), coarse silt (CS) and POC content) in the sediments, to identify the controlling factors (Fig. 4).

Three principal components were selected, which explained $80 \%$ of the total variance. The first component, accounting for $45 \%$ of the total variance, distinguished strongly positively linked trace elements that are the most anthropogenically influenced $(\mathrm{Zn}, \mathrm{Cr}, \mathrm{Cu}, \mathrm{Pb}, \mathrm{Cd})$ and also $\mathrm{P}$, whereas, Clay, $\mathrm{K}$ and $\mathrm{Mn}$ are opposite, indicating a non major control by clay and maganese oxides. These trace elements mostly originated from, domestic waste waters and industrial discharge. The station S3 mentionned above for its contamination origin is strongly linked to this axis. It was supposed that $\mathrm{Cr}$ mostly originated from artisanal activity due to Fez city effluent discharge [1]. The second component, accounting for $23 \%$ of the total variance. Nickel and $\mathrm{Co}$ as well as $\mathrm{Al}, \mathrm{Fe}$, and $\mathrm{Ti}$ were strongly positively related to this axis, whereas $\mathrm{Ca}$ is opposite.This indicated that the least anthropogenically influenced metals ( $\mathrm{Ni}$ and $\mathrm{Co}$ ), are controlled by $\mathrm{Al}$ and $\mathrm{Fe}$ oxides, mainlyFinally, As and Ca were negatively linked to axis 3 (12,5\% of the variance), where $\mathrm{Si}, \mathrm{Na}$ and CS were positively linked to this axis. This means that evaporites (of which $\mathrm{Na}$ originate mainly), did not control any metals and that As is of natural origin since it is very common in sedimentary bedrock $[5,14]$, and it was asssociated to carbonate, which is the dominant bedrock in the Sebou basin. 



Figure 4. 3D representation of PCA for the three main components, considering trace and major elements, Clay, fine Silt (FS), coarse silt (CS) and POC content) in bottom sediments of the Sebou basin.

\section{Conclusion}

The different tools used in this study allowed to understand the geochemical behaviour of trace metals $(\mathrm{As}, \mathrm{Cd}, \mathrm{Co}, \mathrm{Cu}, \mathrm{Cr}, \mathrm{Ni}, \mathrm{Pb}$, and $\mathrm{Zn}$ ) in the Sebou Basin sediments in a natural and anthropogenic contexts. Overall, the results obtained did not show alarming concentrations, except for $\mathrm{Cr}, \mathrm{Zn}$, and $\mathrm{Cu}$ in some stations, and particularly downstream the Fez city.However, to assess the real risks of metal availability, it is imperative to evaluate their labile fraction.

The Principal Component Analysis (PCA) allowed to identify the most anthropized elements $(\mathrm{Zn}, \mathrm{Cr}, \mathrm{Cu}, \mathrm{Pb}, \mathrm{Cd}$ ) which were linked to phosphorus, those who were less impacted by anthropic activity ( $\mathrm{Co}$ and $\mathrm{Ni}$ ) controlled by iron and aluminium oxide and finally, those with natural origin (As) linked to carbonate (the dominant bedrock in the Sebou Bassin).

Aknowlegment : Authors would like to thanks technical teams of EcoLab laboratory from different analytical platforms and the BIZ team for their assistance and help with physico-chemical analysis and part of sample preparation. This work is a part of a cotutelle $\mathrm{PhD}$ (Ibn Tofail University-Toulouse INP) research of Sara EL MRISSANI and of the PHC-Toubkal project O'Sebou. Sara EL MRISSANI received a financial support from PHC-Toubkal via Campus France and the analysis costs were supported by the PHC project as well as by a CNRS contribution in France.

Author Contributions:. For research articles with several authors, a short paragraph specifying their individual contributions must be provided. The following statements should be used "S.E., S.H., J.L.P. and A.P. conceived and designed the experiments; S.S., SH, J.L.P. and A.P. performed the experiments; S.E., A.P. and S.H. analyzed the data; S.E., SH, J.L.P. and A.P. contributed reagents/materials/analysis tools; S.E. and A.P. wrote the paper. SH and J.L.P. have red and approved the paper".

Conflicts of Interest: The authors declare no conflict of interest. The founding sponsors had no role in the design of the study; in the collection, analyses, or interpretation of data; in the writing of the manuscript, and in the decision to publish the results".

\section{Abbreviations:}

ABHS: Agence du Bassin hydraulique du Sebou 


\section{References}

1. Hayzoun, H., Garnier, C., Durrieu, G., Lenoble, V., Le Poupon, C., Angeletti, B., Ouammou, A., Mounier, S. Organic carbon, and major and trace element dynamic and fate in a large river subjected to poorlyregulated urban and industrial pressures (Sebou River, Morocco). J. Sci. Total Enviro. 2015,502, 296-308.

2. Volpe, M., La Cara, F., Volpe, F., De Mattia, A., Serino, V., Petitto, F., Zavalloni, C., Limone, F., Pellecchia, R. Heavy metal uptake in the enological food chain. Food Chem. 2009,117(3), 553-60.

3. Qiu, Y.W. Bioaccumulation of heavy metals both in wild and mariculture food chains in Daya Bay, South China. Estuarine, Estuar. Coast. Shelf Sci., 2015, vol. 163, p. 7-14

4. Rodríguez, J., Tueros, I., Borja, A., Belzunce, M., Franco, J., Solaun, O., Valencia, V. Zuazo, A. Maximum likelihood mixture estimation to determine metal background values in estuarine and coastal sediments within the European Water Framework Directive. Sci. Total Enviro. 2006, 370(2-3), 278-93.

5. N'guessan, Y.M., Probst, J-L, Bur, T., Probst, A. Trace elements in stream bed sediments from agricultural catchments (Gascogne region, SW France): where do they come from?. Sci. Total Enviro. 2009, 407(8), 293952.

6. Pinto, M.M.C., Silva, M.M, da Silva, E.A.F., Dinis, P.A., Rocha, F. Transfer processes of potentially toxic elements (PTE) from rocks to soils and the origin of PTE in soils: A case study on the island of Santiago (Cape Verde). J. Geochem. Explor. 2017,183,140-51.

7. Singh, K.P., Mohan, D., Singh, V.K., Malik, A. Studies on distribution and fractionation of heavy metals in Gomti river sediments - a tributary of the Ganges, India. J. Hydrol. 2005, 312(1-4), 14-27.

8. Birch, G.J. Determination of sediment metal background concentrations and enrichment in marine environments-a critical review. Sci. Total Enviro. 2017, 580, 813-31.

9. Leleyter, L., Probst, J-L. A new sequential extraction procedure for the speciation of particulate trace elements in river sediments. J. Environ. Anal. Chem. 1999, 73(2), 109-28.

10. Charriau, A., Lesven, L., Gao, Y., Leermakers, M., Baeyens, W., Ouddane, B., Billon, G. Trace metal behaviour in riverine sediments: role of organic matter and sulfides. J. Appl. Geochem. 2011, 26(1), 80-90.

11. Casas, J., Rosas, H., Solé, M., Lao, C. Heavy metals and metalloids in sediments from the Llobregat basin, Spain. J. Environ. Geol 2003,44(3),325-32.

12. Hassimi, H., Taleb, A., Bouezmarni, M., Karzazi, O., Taleb, M., Kherbeche, A., Debbaut, V. The effect of the physicochemical conditions variations on the behavior of heavy metals trapped in polluted fluvial system sediments: the case of Oued Sebou, Morocco. Appl. Water Sci. 2019, 9 (1),17.

13. Neto, J.R.A., Andrade, E.M., Palácio, H.A.Q., Sales, M.M.d, Maia, A.R.S. Influence of land use/occupation on water quality in the Trussu river valley, Ceará, Brazil. Rev. Ciênc. Agron. 2017, 48(1), 59-69.

14. Benabdelkader, A., Taleb, A., Probst, J-L., Belaidi, N., Probst, A. Anthropogenic contribution and influencing factors on metal features in fluvial sediments from a semi-arid Mediterranean river basin (Tafna River, Algeria): A multi-indices approach. Sci. Total Enviro. 2018, 626, 899-914.

15. Lamhasni, N., Chillasse, L., Abba, H., El Haouat, S., El Madani, M. Typologie des eaux de surface du bassin du Sebou par multi-approche: corrélation entre indice biologique global des réseaux de contrôle et de surveillance (IBG-RCS) et l'approche physicochimique et microbiologique. Afr. Sci. Rev. Int. Sci. Technol. 2013, 9(2), 35-49.

16. Perrin, J-L., Raïs, N., Chahinian, N., Moulin, P., Ijjaali, M. Water quality assessment of highly polluted rivers in a semi-arid Mediterranean zone Oued Fez and Sebou River (Morocco). J. Hydrol. 2014, 510, 26-34. 
17. ABHS. Inventaire du degré de pollution des ressources en eau dans le bassin du Sebou. Mission 2 : Rapport de l'inventaire du degré de pollution de Sebou. 2014, 174.

18. De Waele, J., Di Gregorio, F., El Wartiti, M., Fadli, D., Follesa, R., Marini, A., Melis, M.T. Geo-environmental risk in the upper valley of the Oued Sebou (Fes, Central Morocco): a preliminary approach. J. African Earth Sci. 2004, 39(3-5), 491-500

19. Koukal, B., Dominik, J., Vignati, D., Arpagaus, P., Santiago, S., Ouddane, B., Benaabidate, L. Assessment of water quality and toxicity of polluted Rivers Fez and Sebou in the region of Fez (Morocco). J. Environ. Pollut. 2004, 131(1), 163-72.

20. Lalami, A.E.O., Merzouki, M., El Hillali, O., Maniar, S., Koraichi, S.I. Pollution des eaux de surface de la ville de Fès au Maroc: typologie, origine et conséquences. LARHYSS Journal P-ISSN 1112-3680/E-ISSN 2011, (9), 2521-9782

21. El Gaidoumi, A., Tanji, K., Chaouni, Benabdallah, A., Taleb, A., Kherbeche, A. Characterization and quantification of heavy metals in Oued Sebou sediments. Sci. World J. 2019, 2019.

22. Snoussi, M., Haïda, S., Imassi, S. Effects of the construction of dams on the water and sediment fluxes of the Moulouya and the Sebou Rivers, Morocco. Reg. Environ. Change 2002, 3(1-3), 5-12.

23. Garzanti, E., Andò, S., France-Lanord, C., Vezzoli, G., Censi, P., Galy V., Najman, Y. Mineralogical and chemical variability of fluvial sediments: 1 . Bedload sand (Ganga-Brahmaputra, Bangladesh). Earth Planet. Sci. Lett. 2010, 299(3-4), 368-81.

24. Carignan, J., Hild, P., Mevelle, G., Morel, J., Yeghicheyan, D. Routine analyses of trace elements in geological samples using flow injection and low pressure on-line liquid chromatography coupled to ICPMS: A study of geochemical reference materials BR, DR-N, UB-N, AN-G and GH. J. Geostandards Newsletter. 2001, 25(2-3), 187-98.

25. Tam, N., Yao, M. Normalisation and heavy metal contamination in mangrove sediments. J. Sci. Total Enviro. 1998, 216(12), 33-9.

26. Chester, R., Stoner, J. $\mathrm{Pb}$ in particulates from the lower atmosphere of the eastern Atlantic. 1973, J. Nature, 245(5419), 27-8.

27. Bounouira, H., Embarch, K., Amsil, H, Bounakhla, M., Foudeil, S., Benyaich, F. Haddad, M. Said, F. Study of heavy metal assessment in the Gharb plain along Sebou river (Morocco) using k0-NAA method at the Moroccan Triga Mark II research reactor. Ann. Agrar. Sci. 2018, 16(4), 376-88.

28. Reimann, C., de Caritat, P. Distinguishing between natural and anthropogenic sources for elements in the environment: regional geochemical surveys versus enrichment factors. 2005, 337(1-3), 91-107.

29. Roussiez, V., Ludwig, W., Probst, J-L., Monaco, AJEP. Background levels of heavy metals in surficial sediments of the Gulf of Lions (NW Mediterranean): an approach based on 133Cs normalization and lead isotope measurements. Environ. Pollut. 2005, 138(1), 167-77.

30. Sutherland, R. Depth variation in copper, lead, and zinc concentrations and mass enrichment ratios in soils of an urban watershed. J. Environ. Qual 2000,29(5), 1414-22.

31. Qu, S., Wu, W., Nel, W., Ji, J. The behavior of metals/metalloids during natural weathering: A systematic study of the mono-lithological watersheds in the upper Pearl River Basin, China. J. Sci. Total Enviro. 2020, 708, 134572. 
(C) 2016 by the authors; licensee MDPI, Basel, Switzerland. This article is an open access article distributed under

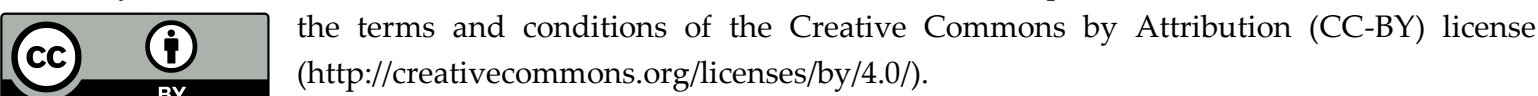

